\title{
BELIEVE ME, DO NOT BELIEVE ME: JHUMPA LAHIRI AND THE ROYAL FAMILY OF OUDH
}

\author{
Alejandra Moreno-Álvarez \\ University of Oviedo
}

\begin{abstract}
In Interpreter of Maladies (1999) Jhumpa Lahiri gives voice to Boori Ma, a durwan (doorkeeper) who chronicles about the easier times she enjoyed before deportation to Kolkata (previously known as Calcutta, India) after Partition of 1947. Lahiri plays with the word real implying that Boori Ma's stories could be deciphered as real or not. Boori Ma's fictitious life resembles the one of the Royal Family of Oudh, which Lahiri seems to be inspired by. Foreign correspondents (Kaufman, 1981; Miles, 1985; Barry, 2019) did not question the veracity of this family's life story. In the present article, the two stories are compared: a literary and a real one. It is our intention to prove that traumatic experiences, such as Partition, cause subjects to imagine an alternative life; strategy which is unconsciously activated to heal trauma (LaCapra, 1999; Mookerjea-Leonard, 2017). The latter is what western journalists and readers failed to acknowledge.
\end{abstract}

Keywords: Partition, Trauma, Literature, Journalism.

\author{
CREÉDME, NO ME CREÁIS: \\ JHUMPA LAHIRI Y LA FAMILIA REAL DE OUDH
}

\section{RESUMEN}

En Intérprete del dolor (1999) Jhumpa Lahiri da voz a Boori Ma, una portera que cuenta a quien quiera escucharle sobre las comodidades de su vida antes de ser deportada a Calcuta tras la Partición de 1947. Lahiri juega con la palabra real, lo que hace que el público lector se cuestione la veracidad de las historias de Boori Ma. Este personaje tiene un paralelismo con el de la familia real de Oudh en la que parece haberse inspirado Lahiri. La prensa internacional (Kaufman, 1981; Miles, 1985; Barry, 2019) contribuyó a que el público occidental no cuestionara la historia de esta familia. En este artículo se comparan ambas historias, una literaria y otra real. Se pretende demostrar cómo experiencias traumáticas, como es el caso de la Partición, hacen que los sujetos, inconscientemente, proyectemos vidas alternativas para así sobrellevar el trauma (LaCapra, 1999; Mookerjea-Leonard, 2017), y cómo, tanto la prensa occidental como el público lector no reparó en este hecho a la hora de analizar ambas historias.

PAlabras Clave: partición, trauma, literatura, periodismo.

DOI: https://doi.org/10.25145/j.recaesin.2021.83.05

Revista Canaria de Estudios Ingleses, 83; November 2021, pp. 67-76; ISSN: e-2530-8335 
In "A Real Durwan," short story included in Interpreter of Maladies (1999), Jhumpa Lahiri gives voice to Boori Ma, a durwan (doorkeeper) who chronicles about the easier times she enjoyed before deportation to Kolkata after Partition of 1947. No one doubts that she is a refugee because of her accent, and, at the same time, no one is sure about her litanies. She recalls being a landowner in her past life, with a two-story brick house, who ended up crossing the border with just two bracelets on her wrist. Now she sweeps the stairs, with a broom as her most precious possession, newspapers which make the function of a bed, and with her life savings tied to her sari's hem. Lahiri plays along the short story with the word realimplying that Boori Ma's tales could be real or not. The residents of the flat building seem to like Boori Ma until she is accused of robbing the stairwell's basin. She implores everybody to believe her, leaving the reader with the feeling of believing, or not, not just her innocence, but her life stories. Boori Ma's fictitious life resembles the one of the Royal Family of Oudh, which Lahiri seems to be inspired by.

The supposedly realstory of the Royal Family of Oudh began when Wilayat Mahal announced herself as Begum of Oudh on the platform of New Delhi's train station in the early 1970s. The Kingdom of Oudh was, as we will further see, a princely state in the Awadh region of North India that no longer exists due to annexation by the British in 1856. The Begum declared that she would stay in the train station until her properties were restored to her. She settled in the V.I.P. waiting room, together with her two children, Prince Ali Raza and Princess Sakina, for a whole decade. People doubted about the truthiness of her status, as tenants do with Boori Ma's one. Thanks to the propaganda broadcasted by foreign correspondents (Kaufman, 1981; Miles, 1985; Barry, 2019), western readers demanded a solution to the injustice committed with Wilayat. Prime Minister Indira Gandhi ended up accepting the family's claim and granted them a 14th century hunting lodge known as Malcha Mahal, in the Chanakyapuri area of New Delhi.

In the present article these two stories are compared: a literary and a realone. Our thesis is that traumatic experiences, such as Partition, cause subjects to imagine an alternative life to heal trauma (LaCapra, 1999; Mookerjea-Leonard, 2017), fact that western journalists and readers seem to have failed to acknowledge. Since Jhumpa Lahiri may have been inspired by the Royal Family of Oudh's case when writing "A Real Durwan," let us analyse what took Wilayat Mahal to declare herself as the Begum of Oudh, to later study how traumatic experiences unconsciously play an important role in the subjects' imagination, to then exemplify the latter in Lahiri's story "A Real Durwan."

In the early 1970s, Wilayat Mahal and two of her children, Cyrus and Sakina, whom she referred to as Prince Ali Raza and Princess Sakina, arrived at New Delhi's train station claiming to be the Royal Family of Oudh. The Begum demanded recognition and accommodation suitable to their noble status. They stood for days at New Delhi's train station platform until they accommodated themselves, together with their watchdogs and servants, in the railway's V.I.P. waiting room. This space became their home for almost a decade. Prime Minister Indira Gandhi, pressured by a possible Muslim revolt ignited mostly by western journalist who let the world know about this presumably Royal Family situation, offered them Malcha 
Mahal, a $14^{\text {th }}$ century palace in New Delhi, where there was no electricity, no running water, but telephone connection. The latter allowed the family to have contact with journalists overseas who contributed, as mentioned, to spread the legend.

The palace, built by Firoz Shah Tughlaq, a Muslim ruler of the Tughlaq dynasty (1351-1388), is nowadays, after the deceased of the so-called Royal Family of Oudh, a tourist attraction to visit. This Indian space, with history, or story as we will try to prove, embedded within its bricks, is now advertised, mainly to international tourists, for having been the home of the so-called Royal Family of Oudh. It is said to be a haunted place due to the stories built around this peculiar family, particularly by western journalists such as Ellen Barry (The New York Times, 2019), James Miles (Los Angeles Times, 1985), Michael T. Kaufman (The New York Times, 1981), Jonathan Broder (Chicago Tribune, 1985), Elizabeth Bumiller (The Washington Post, 1986) or Tim Sullivan (The Seattle Times, 2004), among others. It is our claim that what haunts the place is the trauma of Partition which permeates physical and bodily entities, those of the palace itself, and of Wilayat Mahal. Trauma is what makes us, human beings, unconsciously imagine alternative lives to deal with traumatic experiences, since, as Dominick LaCapra highlights, trauma "is a shattering experience that distorts memory" (2009: 61).

Wilayat Mahal considered herself the Begum of Oudh, and the international press contributed for decades to make readers believe of the real existence of the Begum. Not until 2020 did Devanshi Patel accuse western journalists of exoticizing, once more, India. In "The Jungle Prince and the Western Gaze," Patel underlines how "foreign journalists amplified these fabrications" (2020). Journalists Michael T. Kaufman (1981) and Ellen Barry (2019), among others, provided western readers with the exoticism they were looking for. By exoticizing the Orient, journalists contributed to perpetuate the image of India as a country full of Royal Families, palaces, servants, nawabs and harems, as in The Arabian Nights. That only western correspondents were allowed entrance in the palace, home to the Begum, explains how, following Indian journalist Saeed Naqvi, there was not an acute historical approach which would have proved these journalists wrong: "[h]ad an Indian journalist been allowed access, he or she might have found discrepancies in the family narrative earlier" (in Patel 2020). He calls for single facts, that is, for example, that the so-called Royal Family of Oudh was of Sunni Muslim descent while the Nawabs of Oudh were historically Shia (Naqvi 2019). Western journalists seemed not to be interested in historical facts but in crafting the Begum and her children as objects for the western palate. It is in 2019 when Ellen Barry, after years of research, claims at the end of her article, that the Begum was to be seen as a Muslim housewife who was forced to leave her home in Lucknow and was determined to get all her belongings returned. She finally acknowledged that Partition is what drove Wilayat into a psychotic breakdown. Nevertheless, forty years of international journalist chronicle about the eccentric Royal Family of Oudh failed to associate that this family was a physical representation of the trauma behind Partition.

To understand what Barry calls one of New Delhi's great mysteries (2019), known to western journalists but not to Delhiites themselves, we need to draw a picture about the history of Oudh. Awadh, anglicized as Oudh, was a historic region 
of Northern India, which now constitutes the north-eastern part of Utter Pradesh (state in the northern part of current India), and which was occupied by Muslim invaders in the $12^{\text {th }}$ century, becoming part of the Mughal empire in the $16^{\text {th }}$ century. British became interested in Awadh in 1760 and after 1800 their control exceeded. In 1798 Nawab Saadat Ali Khan was crowned by Sir John Shore, and, as a manifest of gratitude, the nawab gave half of Awadh Kingdom to the British. In 1818 Oudh state declared itself independent from the rules of the "Great Moghul" and it was annexed as Oudh by the British in 1856. This angered Indians, contributing to the Indian Mutiny (1857-1858). Wajid Ali Shah was the last ruler of Awadh who in 1856, before the mutiny, left to Metiabruz, in Kolkata, with part of his family, which included the chief Begum and other members of the harem. Hazrat Mahal, whom it is said to be his favourite, stayed in Lucknow and played a leading role during the 1857 sepoy revolt. She claimed her son, Birjis Qadr, the Wali (ruler) of Oudh, but it was rejected by the British. The Begum escaped to Nepal, and Wajid Ali Shah was survived by many of his children. In 1877 the British controlled the Oudh region and together with Agra became "the United Provinces of Agra and Oudh." After India's independence in 1947 that territory became part of Uttar Pradesh. Begum Wilayat Mahal's husband, who pre-deceased her, is said to be one of Wajid Ali Shah's descendants (Barry 2019). Inayatullah Butt, Wilayat's husband, was in fact a government official, who worked as the register of the University of Lucknow, and not until his death did it occur to the Begum to claim social and economic compensation for their royal ancestry.

Ellen Barry, South Asia bureau chief for the New York Times (2013-2017), received a phone call from Cyrus, Prince Ali Raza, in 2016, inviting her to visit Malcha Mahal. Many journalists, mostly American, had been invited before to the decayed palace, where Cyrus would inform them about the injustices committed towards his family. Michael T. Kaufman, journalist for the New York Times, wrote back in 1981 how the Begum claimed what was hers, "what was wrongfully taken from us" and how "we never accepted British hegemony, and the best they could do was make deals with some offspring of the nawab's concubines." Barry developed a friendship with Cyrus, the last remaining member of the family, and not until his death did she piece together the family's history, coming to the conclusion, in 2019, after four years of research, that they were not the Royal Family of Oudh. With the article "The Jungle Prince of Delhi," published in The New York Times (2019), Barry became 2020 Pulitzer Prize finalist in Feature Writing.

In 2019 Barry went to Lucknow (in Uttar Pradesh), where the family had previously lived, where neighbours remembered them but not as the Royal Family they considered themselves to be. Thanks to Shahid, Cyrus' brother, who lived in Bradford, Barry was able to prove that Cyrus was in fact Mickey Butt. Shahid confirmed that his mother, Wilayat Mahal, was a housewife, and how when his mother claimed to be the Begum of Oudh, he did believe her until he was old enough to realize the fictitious life his mother had constructed upon them and upon herself. He left, and so did his other brother Salahuddin Zahid Butt. The latter migrated to United States. He died in 2017 but Barry interviewed his wife Selma who agreed that her mother-in-law had a mental disorder. The plain story is that 
after Partition, Wilayat Mahal and Inayatullah Butt had to decide about staying in India or moving to Pakistan. Wilayat did not want to leave India but was forced to do so by her husband. She was confined to a mental hospital in Lahore where she received electroshock therapy. It was after that, and once her husband died, when she returned to India and her first stop, now as the so-called Begum of Oudh, was New Delhi's platform train station.

This story has nothing to do with the narrative of enchantment and mystery the international press gave echo to. There is no fairy tale ending either, even though Cyrus, when informing the press about his mother's death, tried to exoticize it by adding fictitious glamour to her suicide. It seems that Wilayat, unable to bear her life situation, killed herself by ingesting a poisonous drink mixed with crushed diamonds back in 1993. Cyrus, the last member of the made-up Royal Family of Oudh, died in 2017 due to dengue fever, his unclaimed body buried in a grave marked with a stone that says DD33B. The aftermath of this traumatic life is that Cyrus' brother Shahid recognized to Barry not knowing if he was Indian of Pakistani, and Cyrus, on the other hand, was buried even without a name on his grave, that is, both deprived of their identity. They all suffered the consequences of their mother mental illness caused by the traumatic effects of Partition. The international press should have acknowledged this when broadcasting the news about the Royal Family of Oudh.

Wilayat's storytelling is an example of what Gabriele Schwab defines as a testimony "necessary for healing trauma" (2010: 48). Her tale was a narrative which dealt with the paradox of telling what she could not tell, not to herself, not to her children, not to the press, that of Partition. Urvashi Butalia highlights how "[t]he political partition of India [in 1947] caused one of the great human convulsions of history. Never before or since have so many people exchanged their homes and countries so quickly. In the space of a few months, about twelve million people moved between the new, truncated India and the two wings, East and West, of the newly created Pakistan" (2000: 3). More than ten million refugees crossed the western border which divided the historic state of Punjab: Muslims travelling to Pakistan, such as Wilayat, and Hindus and Sikhs east to India. Urvashi Butalia reminds us in The Other Side of Silence (2000) how the way people choose to remember their history is as important as what we may consider historical facts (8).

Nonetheless, historical facts are also interpretations of a given person. It was on June 3,1947, when the plan to partition India was announced. A vast number of letters were received by the All India Congress Committee (AICC) concerning people wanting to know what would happen to them: "What will become of us, they asked. We believe India is to be partitioned: where will we go? How will we go? What will happen to our jobs? If we have to move, will we get our old jobs back in the new homeland? What will happen to our homes, our lands, if we have to move?" (Butalia 2000: 55, italics in the original). These concerns, together with the consequences of Partition, and its nowadays ramifications are what the story behind the Royal Family of Oudh and Lahiri's short story "A Real Darwan" gather.

There are many aspects of Partition that remain invisible, but as we see within a contrapuntal reading of both stories, the one of the Royal Family of Oudh, and Lahiri's "A Real Durwan," there is a clamour of voices that want to be 
heard, particularly, the ones that have been marginalized by society, in this case, Wilayat and Boori Ma. Butalia underlines that "[m]any historians have spoken of how selective amnesia and memory are at the root of the relationship between human beings and their history" (2000: 277) and how historiography is a technique which attempts to dissipate amnesia and work on memory. Without a doubt, in the history of Partition, the stories of women, children, castes, and many other have been silenced. Barry slightly mentioned it when writing about the Royal Family of Ouhd, nor did the international journalists who wrote about this family for forty years. Lahiri, perhaps inspired by this story, contributed to voice a subaltern character victim of Partition.

When approaching both texts, a literary and a real one, we need to be aware of the trauma that is behind them, that of Partition. It implies, as we already know, more than a simple geographical division. It refers to "people separated overnight, and friends became enemies, homes became strange places, strange places now had to be claimed as home, a line was drawn to make a border, and boundaries began to find reflection in people's lives and minds" (Butalia 2000: 285). Subjects had to redefine themselves and many of them were clustered in a limbo, as the one Wilayat, her children, and Boori Ma had to inhabit. Fiction allows us to understand such a traumatic experience where empathy is crucial both in writing and reading. As scholar Andrea Llano Busta claims, thanks also to interdisciplinary approaches, such as the one we are here employing, we can move "from a purely historical standpoint to one that prioritized the human dimension of the matter" (2019: 46). Through fiction, Lahiri allows Boori Ma to challenge "hegemonic discourses by drawing attention to the emotional sphere blatantly ignored in historiography" (Llano Busta 2019: 46).

Lahiri also employs LaCapra's empathic unsettlement technique (2001) as she establishes a mode of writing that allows the reader to feel an affective bond with the victim, Boori Ma, without allowing for (over)identification with her (LaCapra 2001: 79-79). This technique helps the reader to acknowledge the represented other and that understanding the other can never be complete, as Emy Koopman suggests (2010: 237). Nevertheless, Lahiri offers a writing, and, with it, a reading which enables "an affective approach without making identification implausible" (Llano Busta 2019: 53).

Antonia Navarro Tejero adds how "[t]he partition narratives of South Asian authors are testimony to the fact that women of all ethnic and religious backgrounds were the greatest victims of the newly created border between India and Pakistan in 1947" (2019: 44). And this is the case of Wilayat and Boori Ma. Lahiri succinctly addresses the violence of Partition when writing the historiography of Boori Ma. The rhetorical apparatus employed dehumanizes this character who had lived an accommodated life before Partition to end up as a durwan with a broom as her most precious possession, first within a household, to later be thrown out from it. Karin Möller underlines how "Lahiri makes Boori Ma carry injustice as an allegorical weight, that is, she is of course powerless to alter the sad historical fate of vast numbers of domestically subaltern women, but she is allowed to leave her trace in the story in a manner that determines its ironic significance" (2008: 67). This irony is constantly present along the story, with the repetition of the sentence "believe 
me, don't believe me" which at the end of the story becomes "believe me, believe me." Lahiri presents a riddle that we need to solve along the story. By repeating the imperative "believe" uttered by the main character, the author pushes the reader to understand that what Boori Ma was telling was the truth. This sixty-four-year-old character, "with a hair in a knot no larger than a walnut, and she looked almost as narrow front as she did from the side" (70) lived before deportation with her husband and four daughters in a two-story brick house. From that past she just has the skeleton keys, two bracelets and her life savings tied to her sari's hem. To whom she encounters along the household stairs, she describes in detail the delicious menu of one of her daughter's wedding: rice cooked in rosewater and pewter bowls for the wedding guests to wash their hands, among many other delicacies. She tells her neighbours, particularly Mrs. Dalal, the wife of a wholesale distributor of plumbing goods, and Mrs. Misra, the only one in the building with a telephone, that her feet, before Partition, "touched nothing but marble" (71). It was back in her past when she tasted a life of luxuries, which contrasts with the life she now lives, where she is practically invisible for the building's residents.

Because of her accent none of the neighbours doubt about her being a refugee: "the accent in her Bengali made that clear" (72). But they do not believe about her wealthy past status because of the misleading recurrent facts she keeps telling, such as that she crossed the East Bengal border "with the thousands of others, on the back of a truck, between sacks of hemp" (72). Other days she would say that she had come to Calcutta [Kolkata since 2001] on a bullock cart. When asked ironically about which was the real means of transport which took her to Calcutta from Bengal, she would reply that there was no need to demand specifics. There is a story within a story where the external one, and, thus, the less relevant, is full of specifics about how Mr. Dal brought two basins to the building, and because his wife did not want the two of them at home, they put one in their house and the other one in the basin. Mr. Dal was being promoted and to celebrate it he took his wife on vacation. The latter, together with the basin, had consequences since the women in the neighbourhood became jealous and decided to plan renovations of their own: "One decided to barter a stack of her wedding bracelets and commissioned a whitewasher to freshen the walls of the stairwell. Another pawned her sewing machine and summoned an exterminator. A third went to the silversmith and sold back a set of pudding bowls: she intended to have the shutters painted yellow" (80).

If we leave aside the specifics, as Boori Ma requests, "Why demand specifics? Why scrape lime from a betel leaf?" (72), and we analyse the internal and most relevant story, we can see that "she is the victim of changing times" (72), as Mr. Chatterjee, a neighbour who stop reading newspaper since Independence, recalls. Like "thousands of others" (72), she left her life back in Bengal and moved to Calcutta. Lahiri gives the reader hints to resolve the riddle as she gives voice to the female neighbours who excuse Boori Ma for her contradictions since "she probably constructs tales as a way of mourning the loss of her family" (72). We need to decipher the reasons why she is no longer with her family. Partition in 1947 is the answer, for it saw thousands of people split according to religion. Ironically, the basin, symbol for religious rituals of cleaning and purity, placed by Mr. Dal in the 
building's corridor contributes to accentuate these changing times Mr. Chatterjee refers both at the beginning and at the end of the short story.

The changing times at the beginning refer to Partition and its oblivion. Meanwhile, at the end of the story, Mr. Chatterjee highlights that people's need to wash the past and offer a new face constitutes a new reality. As he states in the story, "Boori Ma's mouth is full of ashes. But that is nothing new. What is new is the face of this building. What a building like this needs is a real durwan" (82, italics in the original). The basin and the refurnishing of the building washed the building's past and pushes Boori Ma, who reminds them of Partition and its aftermath, to the building's rooftop. She becomes like a witch with a broom that nobody wants to see any longer. It is as if with the disappearance of Boori Ma, the grief of Partition vanishes. This is the hypocrisy that Lahiri is in our opinion criticizing, since we cannot simply forget what Partition caused. As Butalia acknowledges "it exists privately in the stories told and retold inside so many households in India and Pakistan" (2000: 3). The only way we can begin to understand what Partition was, Butalia highlights, is by looking at how people remember it (2000: 10). Boori Ma needs to voice, even altering what really happen, what she went through.

Herstory is part of her identity, and once she climbs to the rooftop because there is no space for her in the building stairs due to the refurnishing she is disposed from her past, as she is not able to voice it. It is then when she leaves the private space and becomes a flaneuse who wanders around Calcutta. Not being able to share about her past with the neighbours she loses control of what she is. This loss is represented by Lahiri when in one of her walks Boori Ma loses her life savings and her skeleton keys. When she goes back to the building neighbours accused her of having informed robbers about the basin that was no longer there. She implores them to believe her, not just her innocence but also her, at times, misleading past. James Young reminds us that "[w]hatever 'fiction' emerge from the survivors' accounts are not deviations from the 'truth' but are part of the truth in any particular version. The fictiveness in testimony does not involve disputes about facts, but the inevitable variance in perceiving and representing these facts, witness by witness, language by language, culture by culture" (1990: 32).

\section{CONCLUSION}

These two stories, a literary and a real one, represent traumatic narratives which could be understood as restoring possibilities of healing and mending (Masterson et al. 2013: 2). Fiction disentangles, within a bibliotherapy strategy, bodies, and words from the traumas which hold them captive. With great success, Lahiri represents the unrepresentable. Literature proves then how, as Cathy Caruth, underlines, it is the appropriate medium to explain the unexplainable because it uses a language "that defies, even as it claims, our understanding" (1996: 5). Wilayat had to fictionalize her life to voice the traumatic experience she had to go through, something that, unfortunately, took time for western journalists to see. Lahiri, who might be inspired by the story of the Royal Family of Oudh, makes a wink to 
the western journalists who wrote about Wilayat. Mr. Chatterjee never opened a newspaper since Independence took place. This could be due to Chatterjee's grief, or it could be understood as a manipulation of how history is being written by historians and journalists alike. On the other hand, Boori Ma, lacking a proper mattress, uses newspapers to lie on. She does not read them but lies on top of them, and when the newspapers got wet due to the rain, her sari "smeared with newsprint ink" (81). When Boori Ma is deprived of her identity and she does not have any more the skeleton keys in her sari's hem, it is when the newspaper ink becomes visible. Wilayat is the outcome of western journalism and Boori Ma is Lahiri's. Nevertheless, if we pay attention to their real and fictional inner story, we realize that they are the aftermath of Partition. 


\section{WORKS CITED}

Barry, Ellen. “The Jungle Prince of Delhi.” The New York Times (22 November 2019). https://www. nytimes.com/2019/11/22/world/asia/the-jungle-prince-of-delhi.html.

Butalia, Urvashi. The Other Side of Silence. Voices from the Partition of India. Duke University Press, 2000.

Caruth, Cathy. Unclaimed Experience: Trauma, Narrative, and History. MD, 1996.

Escobar Sevilla, Jesús. “Transnational Spaces of Recognition in Jhumpa Lahiri's Interpreter of Maladies.” Journal of English Studies 17 (2019):103-126.

Kaufman, Michael T. "Riches Gone, India Princess Reigns in Rail Station." The New York Time (9 September 1981). https://www.nytimes.com/1981/09/09/world/riches-gone-india-princessreigns-in-rail-station.html.

Koopman, Emy. "Reading the Suffering of Others. The Ethical Possibilities of Empathic unsettlement." Journal of Literary Theory 4/2 (2010): 235-252.

Lacapra, Dominick. History and Its Limits: Human, Animal, Violence. Cornell University Press, 2009.

Lacapra, Dominick. Writing History, Writing Trauma. Johns Hopkin University Press, 2001.

Lahiri, Jhumpa. “A Real Durwan.” Interpreter of Maladies. Houghton Mifflin Company, 1999.

Llano Busta, Andrea. "Mark My Words: The Trauma of Abducted Women in Tow Short Stories by Ramapada Chaudhury." Indialogs: Spanish Journal of India Studies 6 (2019): 45-64.

Patel, Devanshi. "The Jungle Prince and the Western Gaze.” The Juggernaut (March 10, 2020). https://www.thejuggernaut.com/jungle-prince-western-gaze.

Masterson, John, David Watson \& Merle Williams. "Mending Wounds?: Healing, Working Through, of Staying in Trauma: an Introduction." Journal of Literary Studies 29:2 (2013): 1-5.

Möller, Karin. "Power Transformations of the Gendered Subject in Three Stories from Jhumpa Lahiri's Interpreter of Maladies." Ed. Kerstin W. Shands. Neither East nor West. Postcolonial Essays on Literature, Culture and Religion. Södertörnshögskola, 2008. 65-72.

Moonerjea-Leonard, Debali. Literature, Gender, and the Trauma of Partition. The Paradox of Independence. Routledge, 2017.

NAQvi, Saeed. "Royal or Not, Still a Tragedy.” The Citizen (1 December 2019). https://www.thecitizen. in/index.php/en/NewsDetail/index/4/17938/Royal-or-Not-Still-A-Tragedy.

Navarro Tejero, Antonia. "Sacks of Mutilated Breasts: Violence and Body Politics in South Asian Partition Literature.” Journal of International Women's Studies 30/3 (2019): 44-50.

Schwab, Gabriele. Haunting Legacies: Violent Histories and Transgenerational Trauma. Columbia University Press, 2010.

Young, James E. Writing and Rewriting the Holocaust. Narrative and the Consequences of Interpretation. Indiana University Press, 1990. 